\title{
TIMING OF LH RELEASE AND OVULATION IN THE POST PARTUM MOUSE
}

\author{
AUDREY S. BINGEL* AND NEENA B. SGHWARTZ \\ Department of Physiology, University of Illinois College of Medicine, \\ Chicago, Illinois, U.S.A.
}

(Received 1st April 1968, revised 16th September 1968)

\begin{abstract}
Summary. The time at which ovulation occurred in post partum mice under L14:D10 (lights on from 05.00 to 19.00 hours) was investigated. Ovulation tended to occur during the late part of the dark period and early part of the light period, but the exact time depended on the time of delivery. Mice that gave birth between 21.00 and 01.00 hours ovulated approximately $26 \mathrm{hr}$ after delivery. The interval between delivery and ovulation decreased the later in the day that delivery occurred, until it became 12 to $13 \mathrm{hr}$ for mice that gave birth between 17.00 and 21.00 hours.

Barbital was administered at various intervals after delivery in an effort to determine the time of release of the LH responsible for ovulation. Although the data indicate that LH release tended to occur in most mice during the afternoon or early evening, there was no one time of day at which barbital was totally effective in blocking $\mathrm{LH}$ release for mice giving birth during different times of the entire 24-hr light and dark period.
\end{abstract}

\section{INTRODUGTION}

In 4-day cyclic rats, LH is released between 14.00 and 16.00 hours (lights on from 05.00 to 19.00 hours) and the animals ovulate about 02.00 hours on the morning of oestrus (Everett, 1961). In the post partum rat under the same lighting conditions (Hoffmann \& Schwartz, 1965), for two-thirds of the females giving birth between 08.00 and 16.00 hours, LH is released the same afternoon and ovulation takes place the following morning; in the remaining third and those giving birth after 16.00 hours, LH is released during the next afternoon and ovulation takes place on the succeeding morning.

In the cyclic mouse housed under the same lighting conditions, it has been shown (Bingel \& Schwartz, 1969b) that the 'critical period' for LH release occurs later (17.00 to 21.00 hours), as does the time of ovulation (closer to 05.00 hours or later). The time of the post partum ovulation in the mouse has been studied only under reversed lighting conditions, $6 \mathrm{hr}$ dark and $18 \mathrm{hr}$ light (D6: L18). In these mice, post partum ovulation occurred approximately 12 to 18

\footnotetext{
* Present address: Department of Pharmacognosy and Pharmacology, University of Illinois College of Pharmacy, Chicago, Illinois, U.S.A.
} 
$\mathrm{hr}$ after delivery, the exact delivery-to-ovulation interval depending on the time of delivery (Runner \& Ladman, 1950). Ladman, Palm \& Runner (1953) interpreted pituitary assay data from the same animals as indicating that amounts of pituitary gonadotrophin capable of inducing ovulation were released within $3 \mathrm{hr}$ after parturition. These apparent differences between the times of post partum ovulation and LH release in the rat and mouse could represent a true species difference or merely be an effect of the different lighting conditions used. The present study was undertaken to ascertain the time of $\mathbf{L H}$ release and ovulation in the post partum mouse under the same lighting conditions previously used in studying the post partum rat and the cyclic mouse.

\section{MATERIALS AND METHODS}

A description of the source, age and housing conditions of the mice, as well as the techniques for obtaining vaginal smears and for determining the occurrence or non-occurrence of ovulation, appears in Bingel \& Schwartz (1969a). Ovaries and oviducts were preserved for histological study for the purposes listed previously (Bingel \& Schwartz, 1969b).

Mice were mated either on the night between pro-oestrus and oestrus, or on the day of oestrus. The male was removed from the female's cage when a copulation plug was found in the vagina. Regardless of whether mating occurred during the day or night, the first morning on which a copulation plug was present was designated Day 1 of pregnancy. Vaginal smears were discontinued when a $2-\mathrm{g}$ increase in body weight was observed.

\section{Time of post partum ovulation}

Pregnant mice were observed for the occurrence of delivery, beginning at 17.00 hours on Day 18. Thereafter, observations were made at intervals that created the following 'delivery periods': A, 21.00 to 01.00 hours; B, 01.00 to 05.00 hours; $\mathrm{G}, 05.00$ to 09.00 hours; $\mathrm{D}, 09.00$ to 13.00 hours; $\mathrm{E}, 13.00$ to 17.00 hours; F, 17.00 to 19.00 hours; G, 19.00 to 21.00 hours. The detailed data concerning a small number of mice whose delivery times partially coincided with two of these consecutive periods (Bingel, 1968) will not be presented.

Initially, laparotomies were carried out under ether anaesthesia at $12 \mathrm{hr}$ post partum and were repeated at intervals of several hours if ovulation had not occurred. By these means, the times of day for a pre-ovulation laparotomy and post-ovulation autopsy for each delivery period were established, determining the time of occurrence of ovulation approximately within a 6-hr interval (see Text-fig. 1).

\section{Delineation of critical period for $\mathrm{LH}$ release}

Barbital ( $400 \mathrm{mg} / \mathrm{kg}$ i.p.) was administered to mice either upon completion of delivery, or at $2,4,6,8,12,16$ or $20 \mathrm{hr}$ after delivery. Controls were injected with saline. Laparotomies were carried out at appropriate post-ovulation times (established in the first part of the study) to determine whether or not ovulation had occurred. 'Blocked' animals were observed subsequently for delayed ovulation. 


\section{RESULTS}

Time of post partum ovulation

Text-figure 1 summarizes the data obtained for the time of post partum ovulation in mice. Ovulation tended to take place between 23.00 and 05.00 hours when delivery occurred between 21.00 and 13.00 hours (Groups A to D) of the immediately preceding dark and light periods. Assuming a 12-hr latent period for LH (Runner \& Palm, 1953), it appears that LH release occurred during the latter half of the light period (13.00 to 15.00 hours) in most of these animals. In a small number of Groups A and B mice, however, LH seemed to be released much earlier (see legend to Text-fig. 1 and footnotes, Table 1). For

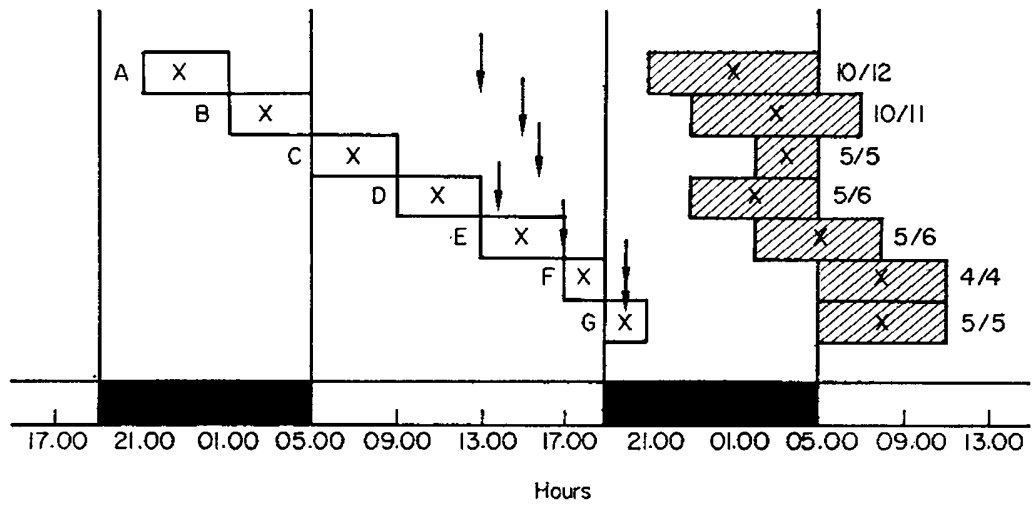

TEXT-FIG. 1. Time of post partum ovulation in mice. Black areas indicate periods of darkness. Open boxes indicate delivery periods for Groups $A$ to $G$, the hatched boxes, the ovulation periods; $\mathbf{X}$ indicates the midpoint of each time period. Arrows indicate beginning of LH release (estimated as $12 \mathrm{hr}$ before the midpoint of each ovulation period). $\mathrm{N} / \mathrm{N}=$ No. of mice ovulated/No. of mice examined. The two Group A and one Group B mice not ovulating within these periods had already ovulated by 21.00 and 23.00 hours, respectively. The one Group D and one Group $\mathbf{E}$ mice not ovulating within these periods were not observed further.

mice giving birth between 13.00 and 17.00 hours (Group E), LH is apparently released just before the onset of the dark period and ovulation takes place close to the onset of the following light period. Furthermore, it appears that in the mice giving birth near the onset of the dark period (Groups F and G), LH release occurs during the early part of the dark period with ovulation, therefore, taking place during the early part of the following light period.

\section{Delineation of critical period for $\mathrm{LH}$ release}

The relative accuracy of the estimated times of LH release indicated in Text-fig. 1 is supported by the data on barbital treatment (Table 1). It can be seen that there is an overall effectiveness of barbital in preventing the occurrence of post partum ovulation (only fifteen of eighty-three barbital-injected mice ovulated by the end of their expected ovulation periods (Text-fig. 1), compared with thirty-seven of forty-one saline-injected ones, $P<0.001$ (Snedecor, 1956)). However, there was no single time of day, nor time in relation to the estimated time of LH release, at which barbital was totally effective in blocking both ovulation and follicular stimulation, the latter indicating that at least some 
LH had been released and had acted on the ovary. Nevertheless, when barbital was administered before the estimated time of LH release for each delivery group, the ovaries of twenty-one out of thirty-nine animals showed no evidence

\section{TABLE 1}

EFFEGTS OF BARBITAL, WITH RESPECT TO TIME OF LH RELEASE, ON OCGURRENCE OF POST PARTUM OVULATION

\begin{tabular}{|c|c|c|c|c|c|c|}
\hline \multirow{3}{*}{$\frac{\begin{array}{c}D \text { to } O \\
\text { interval* } \\
(h r)\end{array}}{26}$} & \multirow{2}{*}{\multicolumn{2}{|c|}{$\begin{array}{l}\text { Treatment } \\
\text { Type Time } \dagger\end{array}$}} & \multirow{3}{*}{$\begin{array}{c}\begin{array}{c}\text { Total } \\
\text { no. mice }\end{array} \\
\begin{array}{r}3 \\
11 \\
4\end{array}\end{array}$} & \multicolumn{3}{|c|}{ Observations $\ddagger$} \\
\hline & & & & Ova & $S F$ & $L F$ \\
\hline & $\begin{array}{l}\text { Saline } \\
\text { Barbital }\end{array}$ & $\begin{array}{l}+ \\
+ \\
-\end{array}$ & & $\begin{array}{l}3 \S \\
4 \\
3\end{array}$ & $\begin{array}{c}-3 \\
1\end{array}$ & $\underline{4}$ \\
\hline$\stackrel{24}{(\text { Group B) }}$ & $\begin{array}{l}\text { Saline } \\
\text { Barbital }\end{array}$ & $\begin{array}{l}+ \\
+ \\
-\end{array}$ & $\begin{array}{l}7 \\
7 \\
6\end{array}$ & $\begin{array}{l}69 \\
2 \\
\end{array}$ & $\begin{array}{l}1 \\
1 \\
6\end{array}$ & $\begin{array}{r}- \\
-\end{array}$ \\
\hline$\stackrel{21}{(\text { Group C) }}$ & $\begin{array}{l}\text { Saline } \\
\text { Barbital }\end{array}$ & $\begin{array}{l}+ \\
+ \\
-\end{array}$ & $\begin{array}{l}1 \\
5 \\
3\end{array}$ & - & $\begin{array}{l}-3 \\
3\end{array}$ & $\frac{-}{2}$ \\
\hline$\stackrel{15}{(\text { Group D) }}$ & $\begin{array}{l}\text { Saline } \\
\text { Barbital }\end{array}$ & $\begin{array}{l}+ \\
+ \\
-\end{array}$ & $\begin{array}{r}5 \\
11 \\
2\end{array}$ & $\frac{5}{1}$ & $-\overline{5}$ & $\begin{array}{l}6 \\
-\end{array}$ \\
\hline$\stackrel{14}{(\text { Group E) }}$ & $\begin{array}{l}\text { Saline } \\
\text { Barbital }\end{array}$ & $\begin{array}{l}0 \\
0 \\
-\end{array}$ & $\begin{array}{r}11 \\
12 \\
8\end{array}$ & $\begin{array}{r}11 \\
2 \\
1\end{array}$ & $\begin{array}{r}- \\
5\end{array}$ & $\begin{array}{r}8 \\
2\end{array}$ \\
\hline$\stackrel{14}{\text { (Group F) }}$ & $\begin{array}{l}\text { Saline } \\
\text { Barbital }\end{array}$ & $\begin{array}{l}+ \\
+\end{array}$ & $\begin{array}{l}8 \\
5 \\
5\end{array}$ & $\frac{8}{2}$ & - & $\begin{array}{l}- \\
1\end{array}$ \\
\hline $\begin{array}{c}12 \\
\text { (Group G) }\end{array}$ & $\begin{array}{l}\text { Saline } \\
\text { Barbital }\end{array}$ & - & $\begin{array}{l}6 \\
4\end{array}$ & 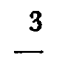 & $\overline{3}$ & $\begin{array}{l}3 \\
1\end{array}$ \\
\hline \multirow[t]{5}{*}{ Totals } & \multirow[t]{3}{*}{ Saline } & + & 24 & 23 & 1 & - \\
\hline & & $\frac{0}{-}$ & $\begin{array}{r}11 \\
6\end{array}$ & $\begin{array}{r}11 \\
3\end{array}$ & - & $\overline{3}$ \\
\hline & & & 41 & 37 & 1 & 3 \\
\hline & \multirow[t]{2}{*}{ Barbital } & $\begin{array}{l}+ \\
0 \\
-\end{array}$ & $\begin{array}{l}39 \\
12 \\
32\end{array}$ & $\begin{array}{l}6 \\
2 \\
7\end{array}$ & $\begin{array}{r}12 \\
2 \\
21\end{array}$ & $\begin{array}{r}21 \\
8 \\
4\end{array}$ \\
\hline & & & 83 & 15 & 35 & 33 \\
\hline
\end{tabular}

* No. of hours between the midpoints of the delivery and ovulation periods (Text-fig. 1).

+ Time of injection: 1 to $12 \mathrm{hr}$ before $(+)$ at time of $(0)$, or 1 to 8 hours after (-) estimated time of LH release (Text-fig. 1).

$\ddagger$ No, of mice with ova, stimulated follicles (SF) only, or large (unstimulated) follicles (LF) only, at the end of the ovulation period for each delivery group, respectively (Textfig. 1).

5 One of these two mice had already ovulated by 21.00 hours, i.e. before the beginning of the ovulation period for its delivery group.

T One of these six mice had already ovulated by 17.00 hours, i.e. before the beginning of the ovulation period for its delivery group.

of LH stimulation. In contrast, when barbital was administered after the estimated time of LH release, only four of thirty-two animals showed no evidence of $\mathbf{L H}$ stimulation. 
The data were further analysed by chi-square techniques (Snedecor, 1956). A significant difference was found to exist at each treatment time between the saline- and barbital-treated mice according to whether the animals had ovulated, showed LH-stimulated follicles, or showed no LH stimulation at the expected time of ovulation for their respective delivery groups: before LH release, $P<0.001$; at the time of LH release, $P<0.001$; after $\mathrm{LH}$ release, $P=0.01$. A significant relationship was also found to exist among the times at which barbital was administered (before, at the time of, or after LH release) and whether the animals had ovulated, and showed, or did not show, stimulated follicles $(P<0.005)$. The data from saline-treated animals also showed this relationship $(P<0.001)$ the cause of the significance apparently being traced to the three mice belonging to Delivery Group G (Table 1) that had not ovulated by the time expected for that group (Text-fig. 1). These animals did ovulate 18 to 24 $\mathrm{hr}$ later. Other mice (both untreated and saline-injected) whose delivery times occurred partially within the 19.00 to 21.00 hours interval, also ovulated at quite variable intervals after delivery, ranging from $12 \mathrm{hr}$ to as long as $34 \mathrm{hr}$ (Bingel, 1968).

Twenty-seven of the thirty-three mice which were totally blocked by barbital were observed for delayed ovulation. Nineteen of them had ovulated or begun to ovulate by 18 to $24 \mathrm{hr}$ after the time expected for their respective delivery groups; two others showed stimulated follicles in their ovaries $18 \mathrm{hr}$ after the expected time of ovulation.

\section{DISCUSSION}

In the post partum rat, the critical period for LH release and the interval during which post partum ovulation occurs are broader than they are in the 4-day cyclic rat (Hoffmann \& Schwartz, 1965). Bingel \& Schwartz (1969b) have shown that under the same lighting conditions (L14:D10) the time of ovulation in both 4- and 5-day cyclic mice is later and more variable than in the cyclic 4-day rat, and that the time of LH release, at least in the 5-day mouse, is later than in the 4-day rat. The present study has shown that post partum ovulation in the mouse, like cyclic ovulation, tends to occur during the late part of the dark period or early part of the light period (lights on from 05.00 to 19.00 hours, Text-fig. 1). However, there was a somewhat greater variability in the time of post partum ovulation (see Text-fig. 1 and footnotes, Table 1), and the actual time of ovulation depended to some extent on the time of delivery. Assuming a 12-hr latent period for LH (Runner \& Palm, 1953), these observed times of ovulation (Text-fig. 1) imply that LH release occurred during the afternoon and early evening.

The critical period for LH release apparently can occur later in the day in the post partum mouse than in the post partum rat. Rats delivering after 16.00 hours did not release LH until after 13.00 hours the following afternoon; in contrast, under the same lighting schedule, virtually all mice delivering before 19.00 hours and most of those delivering between 19.00 and 21.00 hours, released LH during the same evening. On the other hand, when the critical periods for 
LH release in the cyclic and post partum mouse are compared, this period is seen to begin earlier in the post partum animal; it apparently lasts as late but probably no later than in the cyclic mouse (Bingel \& Schwartz, 1969b). Barbital was totally effective in blocking LH release in the cyclic mouse when injected between 14.00 and 17.00 hours at pro-oestrus (Bingel \& Schwartz, 1969b). However, barbital given to the post partum mouse in the late afternoon (Table 1) was totally effective in blocking LH release only when delivery had occurred in the late afternoon; when mice gave birth early in the day, LH was apparently released during the afternoon.

The data obtained in the present study also contrast with the previous observations made in the post partum mouse under D6:L18 (Runner \& Ladman, 1950). In that study, mice giving birth between 21.00 and 01.00 hours $(00.00$, colony time $=$ midpoint of the dark period) ovulated approximately $18 \mathrm{hr}$ after delivery; still assuming a 12-hr latent period for LH, it would appear that these animals released LH about $6 \mathrm{hr}$ after delivery. Under L14:D10, however, most of the mice giving birth between 21.00 and 01.00 hours ovulated approximately $26 \mathrm{hr}$ after delivery (Text-fig. 1), LH presumably having been released about $14 \mathrm{hr}$ after delivery. In both studies, the interval between delivery and ovulation decreases the later in the day that delivery occurs, until it is 12 to $13 \mathrm{hr}$ for mice giving birth between 17.00 and 21.00 hours. When mice gave birth close to the onset of the dark period, therefore, $\mathbf{L H}$ was released immediately after delivery. Interestingly, the mice giving birth between 21.00 and 01.00 hours, under both $\mathrm{L}: \mathrm{D}$ ratios, constitute the group in which the transition takes place from mice in which LH is released immediately after delivery to those in which LH release is delayed longest. In the present study, LH release was delayed also in a small number of mice giving birth between 19.00 and 21.00 hours; perhaps this delay is related to the fact that the dark period began at 19.00 hours, whereas in the former study it began $2 \mathrm{hr}$ later, at 21.00. These contrasting observations may, of course, represent the effect of a strain difference in the mice used. Alternatively, variations in the $\mathrm{L}: \mathrm{D}$ ratio to which post partum mice are exposed may be able to influence the time of LH release; depending on the $\mathrm{L}: \mathrm{D}$ ratio, the time of $\mathrm{LH}$ release may be tied more closely either to the time of delivery (Runner \& Ladman, 1950) or to the time of day (Text-fig. 1).

A comparison of the results of the present study and those of previous ones in both the mouse and rat (Runner \& Ladman, 1950; Everett, 1961; Hoffmann \& Schwartz, 1965; Bingel, 1968; Bingel \& Schwartz, 1969b) clearly indicates the importance of the light-dark environment in regulating the time of $\mathbf{L H}$ release and ovulation during the oestrous cycle as well as at parturition. In the mouse, however, additional factors such as strain differences (Braden, 1957) and the odour of the male (Whitten, 1966) apparently also play a role. Nevertheless, a dependence (although apparently less strict) on the L:D ratio for regulation of the time of $\mathrm{LH}$ release and ovulation has been demonstrated in the mouse, similar to that previously found in the rat. In both species, whether in the cyclic or post partum state, the most favoured time for the LH release responsible for ovulation lies in the second half of the light period, but later in the mouse than in the rat. 


\section{ACKNOWLEDGMENTS}

The authors wish to thank Mr William L. Talley who prepared the tissues for histological examination. This study was supported in part by PHS Grants HD-00440 and T01GM00738.

This work was submitted by one of us (A.S.B.) in partial fulfilment of the requirements for the degree of Doctor of Philosophy in Physiology, University of Illinois.

\section{REFERENCES}

BrNGeL, A. S. (1968) The timing of cyclic and post-partum ovulation in the mouse. Ph.D. thesis, University of Illinois, Chicago.

Bingel, A. S. \& SchwarTz, N. B. (1969a) Pituitary LH content and reproductive tract changes during the mouse oestrous cycle. $\mathcal{F}$. Reprod. Fert. 19, 215.

Bingel, A. S. \& Schwartz, N. B. (1969b) Timing of Lh release and ovulation in the cyclic mouse. 7. Reprod. Fert. 19, 223.

Braden, A. W. H. (1957) The relationship between the diurnal light cycle and the time of ovulation in mice. F. exp. Biol. 34, 177.

Everetr, J. W. (1961) The mammalian female reproductive cycle and its controlling mechanisms. In: Sex and Internal Secretions, 3rd edn, Vol. I. Ed. W. G. Young. Williams \& Wilkins, Baltimore.

HofrmanN, J. G. \& Schwartz, N. B. (1965) Timing of post-partum ovulation in the rat. Endocrinology, 76,620 .

Ladman, A. J., Palm, J. E. \& Runner, M. N. (1953) Bioassay of mouse pituitary gonadotropin by induced ovulation in pregnant mice. Evaluation and biologic application. Proc. Soc. exp. Biol. Med. 84, 582.

Runner, M. N. \& Ladman, A. J. (1950) The time of ovulation and its diurnal regulation in the postparturitional mouse. Anat. Rec. 108, 343.

Runner, M. \& Palm, J. (1953) Transplantation and survival of unfertilized ova of the mouse in relation to post-ovulatory age. F. exp. Zool. 124, 306.

SNEDECOR, G. W. (1956) Statistical methods, 5th edn, p. 225. Iowa State University Press, Ames.

Whitten, W. K. (1966) Pheromones and mammalian reproduction. Adv. reprod. Physiol. 1, 155. 